\title{
BANCO DE BILBAO HEADQUARTERS: FIRST LOW-ENERGY BUILDING IN SPAIN?
}

\author{
César Martín Gómez ${ }^{1}$
}

\begin{abstract}
Francisco Javier Sáenz de Oiza was perhaps the greatest architect of the twentieth century in Spain, and his masterpiece was the Banco de Bilbao Headquarters, located in the Paseo de la Castellana in Madrid (Spain).

Sáenz de Oiza was a university professor in the Installations and Energy Areas at the University of Madrid. For him, concepts such as indoor comfort, lighting, heat production, cooling, and solar houses were an indispensable part of the student's learning and, of course, he included them in his building design. He applied these concepts in the Banco de Bilbao Headquarters.

Therefore, the purpose of this paper will be to examine the Banco de Bilbao technical knowledge in depth - including its passive architectonical design — and to present the main good decisions (and mistakes) of this first low-energy Spanish building after almost 30 years of intensive use, to extend its lessons for future buildings.
\end{abstract}

\section{KEYWORDS}

office building, design techniques, Sáenz de Oíza, façade radiation, skyscraper

\section{INTRODUCTION}

The 1970s provided many examples of architecture in Spain with very interesting solutions to equipping facilities, like the Spanish National Telephone headquarters by Cano Lasso, the Bankunion Headquarters by Corrales and Molezun, and the Sacred Heart Hospital by Leopoldo Gil Nebot.

This is a period in time when "the buildings belonging to banks quickly took on the precepts of an international style, as occurred with geometric volume: straight lines, flat surfaces and flexible floor space (within a technical building language). Volume and verticality were envisioned as the utmost in the abstraction of capitalistic accumulation and became the most demanded forms of expression by this architecture of prestige" [1]. When carefully observed, this description is purely formal. It is also where we situate the Banco de Bilbao headquarters building, considered by many to be one of the best buildings of the twentieth century in Spain. Included within its innovative design were innovative active and passive energy-saving features.

${ }^{1} \mathrm{Ph}$. D. Architect, Universidad de Navarra, School of Architecture, Installations and Energy Section, Tel. +34948 425600 Ext. 2702, Fax +34948 425 629, cmargom@unav.es, www.anav.es/arquitectura. 


\section{METHODOLOGY}

The description of this building's active and passive behavior will begin with a short description of its architect, then we will analyze the building's program, its energy-saving design, and finally draw some conclusions.

It must be stated here that the methodology followed and the results presented are based on the line of research called "A Critical History of Spanish Architecture in the Twentieth Century," presently being undertaken by the School of Architecture of the University of Navarre.

\section{THE ARCHITECT}

Francisco Javier Sáenz de Oíza as a professor has not only influenced various generations of architects but also the integration of facility systems in Spanish architecture in the second half of the twentieth century.

In addition to these more or less well-known aspects of his work, for this paper we consulted Benedicto Aguilera Maria, who holds a Ph.D. in Engineering and who collaborated closely with Sáenz de Oíza on the Banco de Bilbao headquarters' facilities. His opinions, formulated as a result of having worked for Sáenz de Oíza during a four-year period on this project, serve to provide an in-depth look at its planning and construction stages. $\mathrm{He}$ recalls: "Oíza possessed a gifted mind, but we cannot speak about normal organization in his case because he did not use draftsmen or office workers. His kind of organization consisted of using a pencil which didn't even have an eraser and from which his definitive plans were drawn, skipping the rough sketch stages. His drawings were admirable. He possessed an 'oceanic' culture. Any theme was always approached in-depth. Doubt, for him, was a source of creativity [...]. The most impressive thing about Sáenz de Oíza was that everything he touched was converted into something transcendental. A building's structure, a simple staircase, a support, or a grating, were all studied in depth, and in detail, to the very end. He possessed the very uncommon virtue of minutely analyzing everything down to the last detail so as to later ascend to a synthesis leading to the most adequate solution" [2].

\section{THE BUILDING}

The building, which serves as the Banco de Bilbao headquarters, is situated in the Castellana Promenade in Madrid and is the result of a successful bid for a specific site forming part of an urbanism plan by Azca and A. Perpiña in 1954 (Fig. 1). The competition was held between 1971-1972; the project execution took place between 1972-1974; and the building's actual construction between $1974-$ 1981. This was all completed with a budget of 2.200.000.000 pesetas.

FIGURE 1. Banco de Bilbao, Madrid, 2007, exterior perspective.

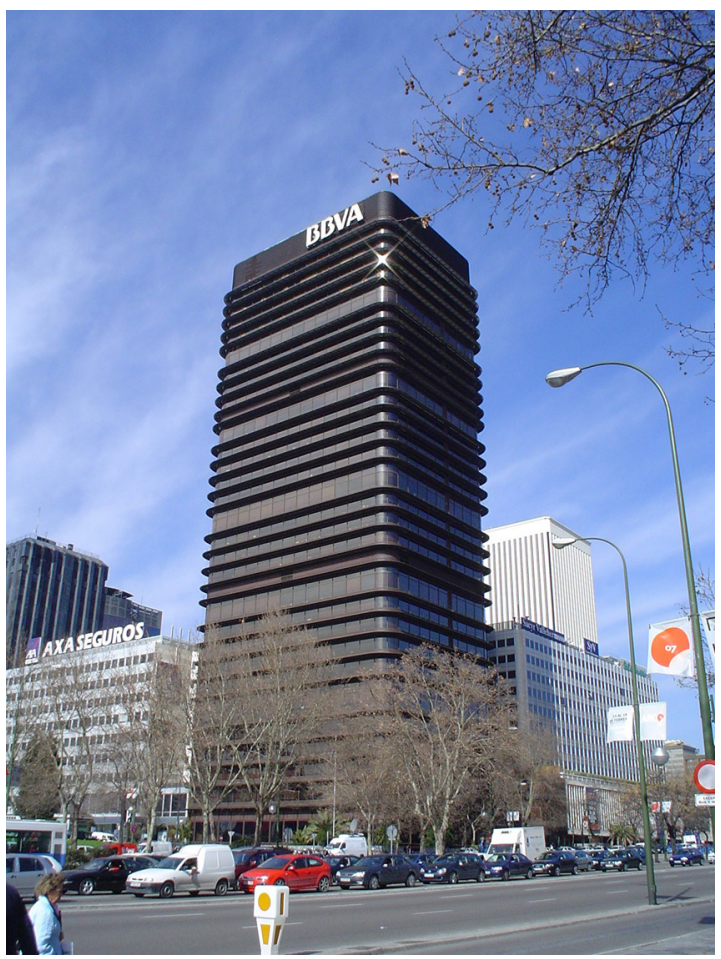


In the project description, Sáenz de Oíza explains that an office building must be understood as both an institution and an instrument for work, much like a complex mechanism possessing great mobility, allowing it to relate to the different forms of the organization-its systems of production and services. In other words, the office building had to be understood as the nuclear basis of the nervous system of urban centers.

The project is executed in a 28-story building on a gradient, in addition to two technical mezzanines and an upper section measuring three meters fifty centimeters for machinery and elevators, refrigeration towers, etc. It also features a three-story parking lot for two hundred cars and a control room for facilities in the lowest-situated basement.

\section{PASSIVE DESIGN OF BUILDING}

Sáenz de Oíza "did not propose an air cushion between the glazing used so that in summer it was necessary to consume a great deal of energy to salvage the green-house effect and cool the 'hyperspace' Sáenz de Oíza did not want the transparent pneumatic curtain. He wanted shade to be palpably present, true to the Mediterranean culture (and fewer calories despite the ageold confrontation with the architect Gutierrez Soto)" [3].

Sáenz de Oíza's understanding of the need for solar protection in a glass building was set forth in his article "Arquitectura y vidrio" in 1952 (Fig. 2): "We cannot but emphasize that the need for both good lighting and adequate protection of glass from direct solar radiation

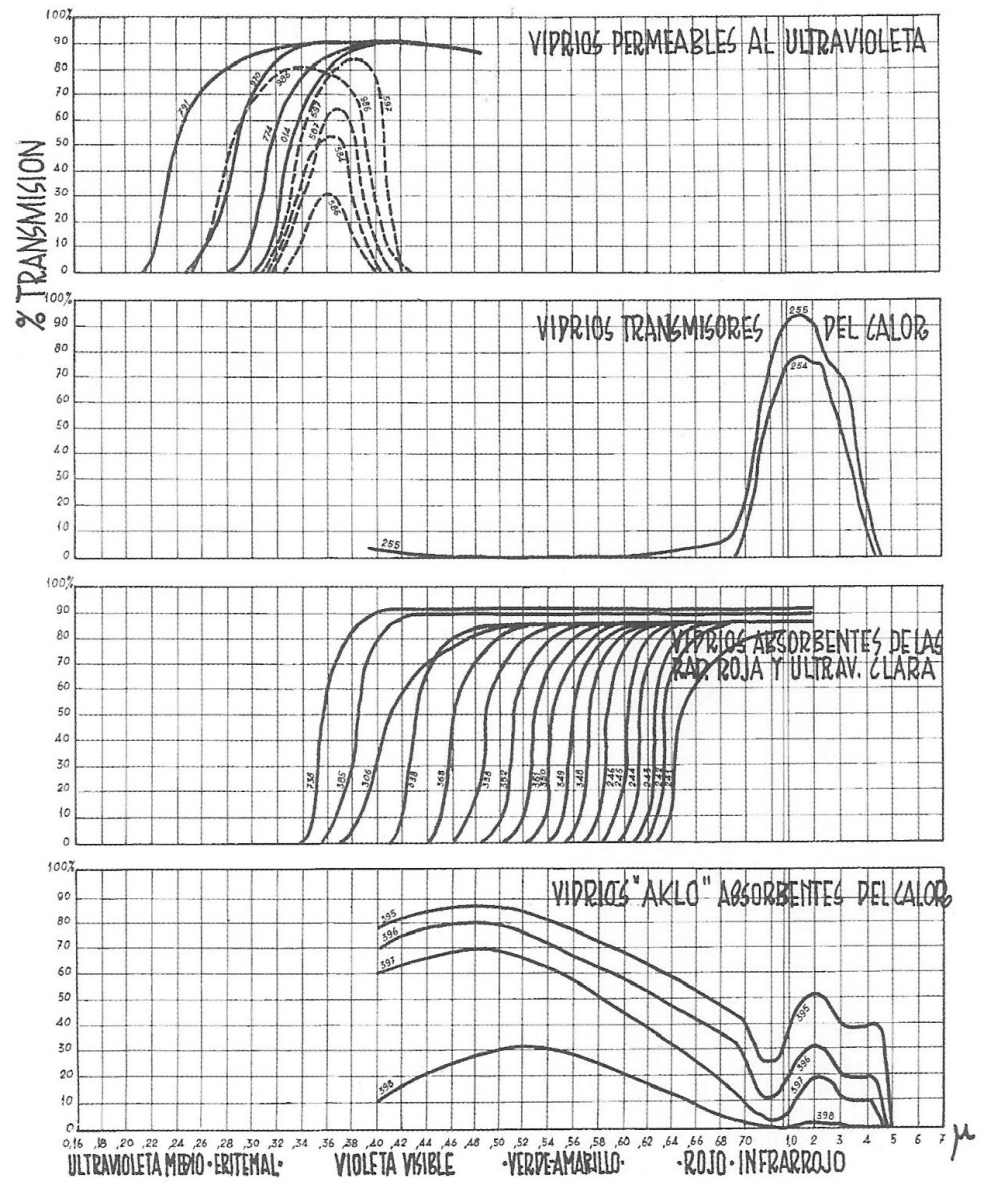

FIGURE 2. Graphic illustration of glass performance according to its components in the transmission of solar energy. Wavelength is represented in abscissa and in ordinates for the percentage of energy transmitted [4]. This graphic display is testimony of Oíza's knowledge of glazing twenty years before the Banco de Bilbao headquarters commission. 
FIGURE 3. Banco de Bilbao, Madrid, 2008, Corner Marquesina and solar protection details, photographer: César Martín Gómez.
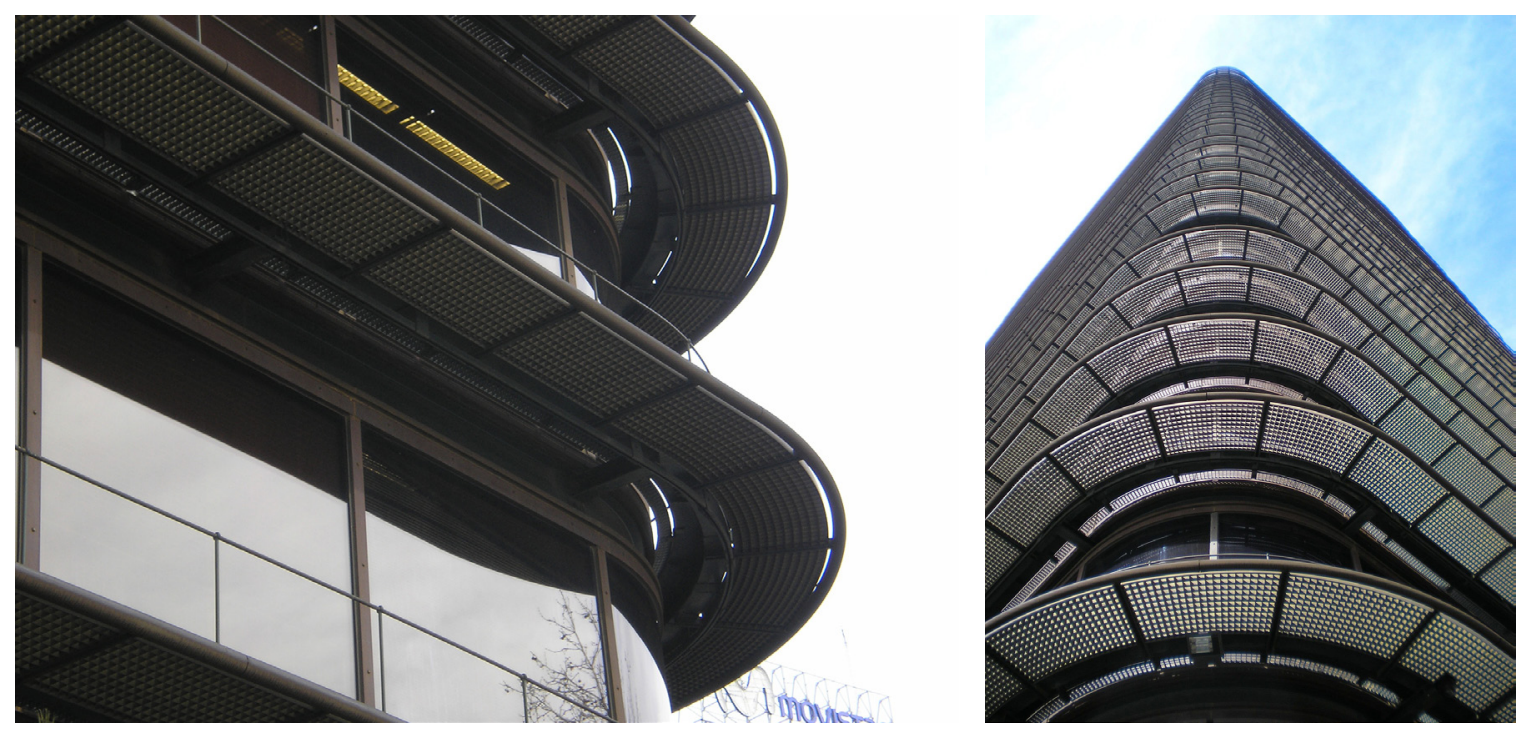

(crucial data in cooling facilities) has led to the adaptation of screen or visors" [4]. This comment is further developed with his discussion of the need to create "permeable voids facilitating the revitalizing action of the sun's rays (a radiation close to ultraviolet) and conversely opaque to thermal transmission so as to not only prevent heat and cold penetration but also to reduce to a minimum the thermal consumption of the climate created by the building's artificial systems" [5].

The building is protected in its exterior by double glazing, which envelops it with a bronzecolored watertight chamber serving to reduce light and thermal transmission, thus obtaining the most efficient energy-consumption performance available in the market at that time.

On the other hand, the aggressive effect of direct solar radiation on thermal increase is avoided through the installment of a horizontally-linear row of parasols in each story that also serve to facilitate the cleaning and maintenance of the building's façade (Fig. 3). The parasol's rings are separated from the closures, thus creating a natural ventilation flowing upwards that can be adjusted depending on sun exposure. The northern façade is reduced to a pathway used for cleaning and maintenance while the south, east, and west-facing façades prolong the pathway with a light brise soleil, which prevents direct solar exposure in the hottest months of the year. In the southern façade, from the tenth story onwards (a nearby building reaches this same height), additional protection is provided through vertical glass parasols in a pale green shade, which serve to buffer the heat and prevent the accumulation of direct solar radiation.

Sáenz de Oíza thus creates a prism which can be orientated in diverse ways depending on the solar exposure experienced at the moment. The criterion used, which always serves to complement the constructive solutions set forth, allows for the alteration of the formal homogeneity of the Banco de Bilbao headquarters façades.

The horizontal brise soleils formed by steel cantilevers and aluminum gratings - in the same bronze color as the exteriors and its joinery-provides up to $24 \%$ reduction in solar 
radiation in the façade's south-facing glazing. This solar protection is quantified in the following data:

- 3,100 linear meters of walkway with a protective balustrade

- 3,600 square meters of parasol — of which 3,000 square meters are of a metal and aluminum framework and 600 square meters of double glazing

- 18,000 linear meters of neoprene joinery to prevent vibration and galvanized rafters

\section{INSTALLATIONS}

"Sáenz de Oíza proposed in the new Banco de Bilbao headquarters in Madrid a control bridge of concrete, metal and glazing to save energy with a well-thought out technique called low emission technology" [6]

The Bank of Bilbao headquarters had been in Bilbao and transferring it to Madrid was a very important decision. In addition, Madrid in those years had very serious pollution problems, so it was of utmost concern to transmit the image of a clean building that contributed to a clean atmosphere (what today we refer to as a bio-climate). It was to be the Banco de Bilbao's contribution to a cleaner Madrid. "A study of the technical blueprints reveals the clarity of the scheme from its start. Electricity would be the sole source of energy and the engineer Benedicto Aguilera would develop the climate and lighting systems as initially proposed in the first version of the project submitted for competition" [7].

The initial concept, therefore, of a building as a "battery" and the use of energy set forth in the building's design are crucial. It is a concept that could have been inspired by all of the technical bibliography related to submarine facilities (Fig. 4).

In this proposal, nonetheless, the fact that the source of electric power is not a clean one is overlooked along with the amount of energy saved. It was basically not the primary concern in the design of the headquarters of a bank that was meant to be emblematic. Yet it did become a very valuable feature because energy consumption was considered an important expense in building maintenance and had to be minimized.

In the building engineer Aguilera's offices, and throughout Spain, there exists a great deal of bibliography in both Spanish and English focusing on this building's unique facilities and specifically on its air conditioning systems. From the outset, Oíza proposed that the actual physical location of the building's facilities be positioned on the platform edges, thus making

FIGURE 4. Publicity for 'Tudor' brand electrical batteries for submarines.

Source: U. Gabler, Submarine Construction, (Spain, San Martin Publisher, 1978) 98.

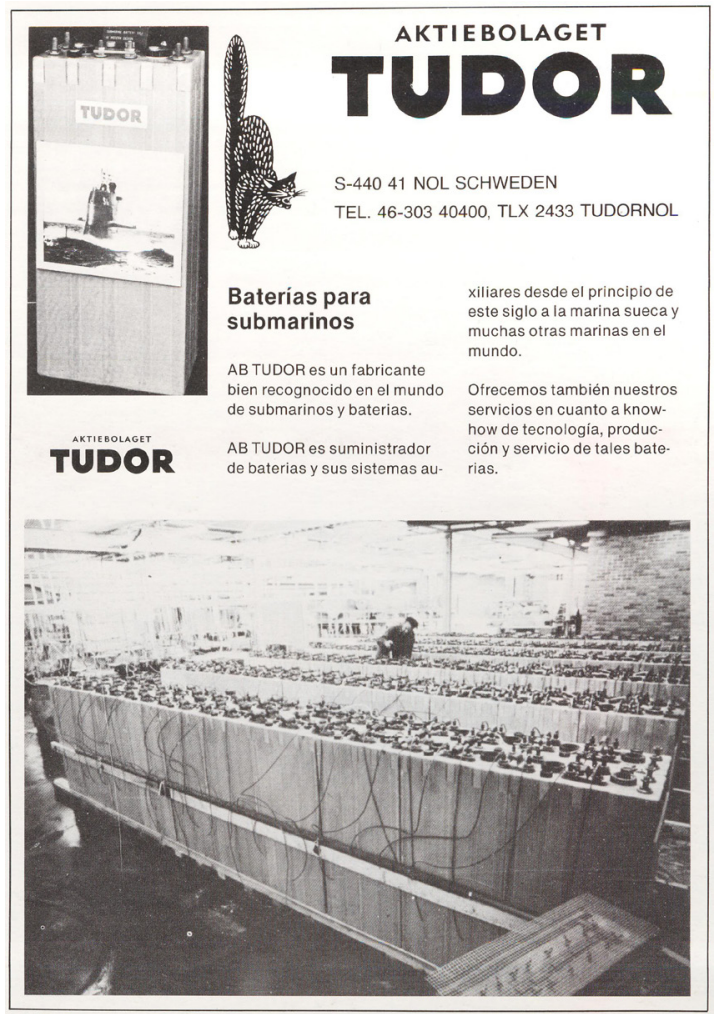


each grouping of facilities autonomous, not only in functioning but structurally and technologically. The Bank of Bilbao headquarters' offices included different sectors within the building, some of which were meant for independent rental of offices. Working with structural engineers, the independent facilities were finally situated in the platform crossbeams.

This approach materializes in facilities possessing the following main components as described by Sáenz de Oíza himself:

- An electrical thermal power plant capable of producing 3,870,000 kcal/h "without polluting or contaminating the atmosphere." It must be stressed here that the Banco de Bilbao headquarters building was the first office building to use electricity as its sole source of energy. Refrigeration plant, capable of producing 36,000 kfrig/h.

- 25 air-handling units that move $376,440 \mathrm{~m} 3 / \mathrm{h}$ of recycled air through 3,000 diffusers. 32 extractors, capable of exhaling $361,325 \mathrm{~m} 3 / \mathrm{h}$ of stagnant air. 72 electro-pumps that move 3.888,570 liters / hour of water.

- 57,500 linear meters of hydraulic circuit pipes. 22,000 linear meters of air ducts.

- The total weight of the aforementioned material is 2,000 tons.

The transmission of caloric energy within the building is carried out through the use of water as a means of transporting energy, a decision forced by the minimum space provided in the suspended ceilings. Thus, centralized production of hot and cold water is pumped first to the technical plants, where this energy is transformed into air that is heated or cooled in the air recycling units and later conducted to secondary hot and cold circuits (cold water movement and return or hot water movement and return).

The building's facilities are controlled through a mixed electronic/pneumatic system, similar to the one installed in New York City's Twin Towers and other buildings in Spain. The control room was situated on the first floor where there is a display chart indicating all the main data for all of the facilities, including elevators, fire alarms, electricity, and air conditioning.

Today, the building's facilities continue to be modified in order to adapt it to the changing demands of the 1,500 people who occupy it (more than twice the initial amount of 600 occupants) and the necessary "state of the art" computer technology required in the headquarters of any modern bank.

\section{SOLAR RADIATION ANALYSIS}

To better analyze the building's solar exposure, its geometric features have been introduced into the 'Ecotect' calculus program, using the radiation data available for Madrid. With the data obtained, it can be confirmed that there is a substantial reduction of solar radiation on the façades, as was initially proposed by the architect in his project. The images in Figure 5 illustrate different times and days of the year.

\section{CONCLUSION}

After the building's study was completed, Aguilera was asked what he least liked in this emblematic project's facilities. His reply was simply: "many things." If he were to design the facilities again, he would not install electric boilers; instead he would use gas boilers and situate them on the roof. He would now insist on installing the intermediary technical plants higher up in the building in order to maximize maintenance. He would also propose the 
FIGURE 5. Summary Chart of the building's solar exposure, Madrid, 2009, Façades studies, Author: César Martín Gómez.

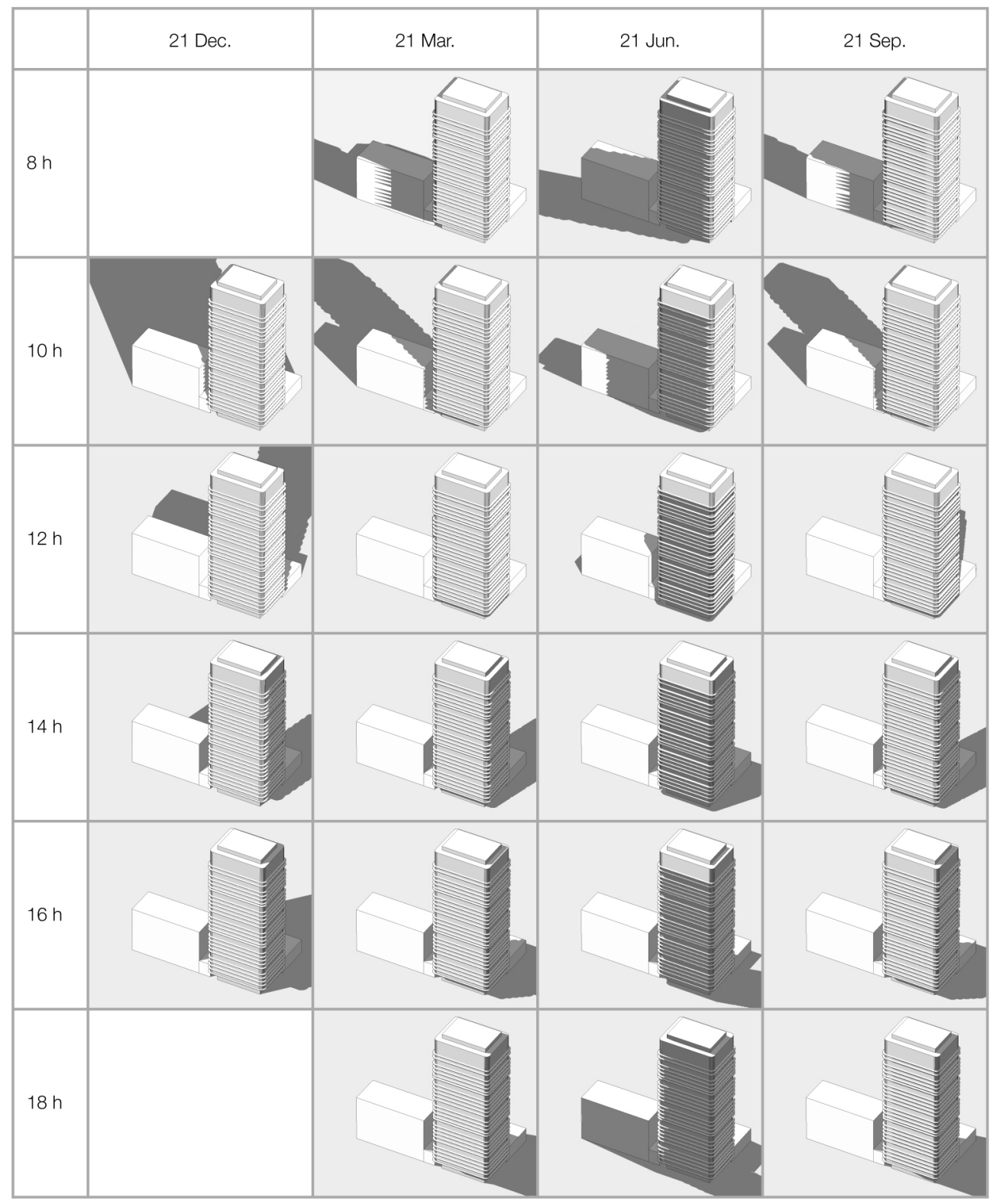

installment of energy recycling systems, which back in the 1970 s were considered to be a luxury in terms of the price of energy and the added cost per square meter built.

With respect to the active and passive design of energy consumption within the building itself, the inclusion of elements like solar protection differentiated by façades and the design of inductors, allows for a uniform thermal space that can facilitate any type of floor distribution. Thus, distribution strategies in the buildings' interiors-both structurally and functionally-now render office floors that are diaphanous throughout the four façades and also functionally flexible. 


\section{ENDNOTES}

1. J. Sobrino, Arquitectura industrial en España (Madrid, Spain, Ediciones Cátedra, 1996), 322.

2. Benedicto Aguilera to César Martín Gómez, 26 April 2007.

3. Departamento de Proyectos, ed., Banco de Bilbao (Madrid, Spain, ETSAM-UPM, 2000),16.

4. F.J. Sáenz de Oíza, "El vidrio y la arquitectura", RNA, 129-130, 1952, 33.

5. F.J. Sáenz de Oíza, "El vidrio y la arquitectura", RNA, 129-130, 1952, 33. Note the manner in which Sáenz de Oíza discusses "the passage of heat and cold from exteriors" and not the heat and cold which enters or leaves the building" which would be the correct description for this physical phenomena.

6. Departamento de Proyectos, ed., Banco de Bilbao op. cit, 15.

7. Departamento de Proyectos, ed., Banco de Bilbao op. cit, 126. "Around the year 1971 the architecture competition for Banco de Bilbao headquarters began to materialize. Sáenz de Oíza and his engineers thought of an electric building: a voltage battery. Even today the source of this type of energy is contaminating some faraway place but it is hoped that renewable, clean (solar, wind-turbine) will substitute the present one. What will only remain will be that pollution resulting from the production of such energy. [...]Sáenz de Oíza wanted a building with a low basal metabolism that needed a minimum amount of energy to maintain comfort levels; a living, economic organism". Idem. 